\title{
ARCHIWA W PRZESTRZENI. LUDZIE, MIEJSCA, DZIAKANIA. WPROWADZENIE DO PROBLEMATYKI OBECNOŚCI ARCHIWÓW W PRZESTRZENI PUBLICZNEJ
}

Słowa kluczowe: publiczna przestrzeń archiwów, użytkownicy archiwów, archiwa cyfrowe, społeczne funkcje archiwów

\section{Streszczenie}

Celem artykułu jest wprowadzenie do rozważań nad współczesną obecnością polskich archiwów w przestrzeni publicznej ze szczególnym uwzględnieniem archiwów państwowych. Zwrócenie uwagi na ich otoczenie oraz wagę podejmowanych działań, ale także zaproszenie do dyskusji nad obszarami ich aktywności, wykorzystywanymi narzędziami oraz perspektywą zmian mentalnych i organizacyjnych. Obecność archiwów w przestrzeni publicznej jest bezsporna. Gwarantuje ją przede wszystkim ich fizyczność: gmach, ludzie, zasób. Są jednak obecne także w wymiarze wirtualnym. Jako archiwa cyfrowe, chmury danych binarnych, elektroniczne repozytoria zasobów cyfrowych. Wykorzystują wirtualną rzeczywistość, by komunikować się z grupami interesariuszy i by czerpać informacje o świecie i ludziach, swych realnych i potencjalnych użytkownikach. Opracowują elektroniczne pomoce archiwalne, by je udostępniać w świecie cyfrowym i tworzyć wielowymiarowy system informacji o archiwach i ich zasobie. I wreszcie, archiwa są obecne w sferze emocjonalnej. Jako archiwa pamięci, tezaurusy wspomnień, źródła tożsamości, samostanowienia i poczucia ciągłości trwania. To relacje, które ludzie budują i które odkrywają, badając archiwalia. Te trzy wymiary - fizyczny, wirtualny i emocjonalny - wzajemnie się krzyżują, dopełniają i współtworzą środowisko, w którym archiwa funkcjonują. Tworzą publiczną przestrzeń archiwów. Bardzo istotnym elementem tej przestrzeni jest otoczenie. Ludzie i instytucje, które wchodzą z archiwami w relacje, tworzą publiczność, kształtują opinię, recenzują działania. Otoczenie, które powinno mieć realny wpływ na funkcjonowanie archiwów, realizowane zadania i ich organizację oraz na które oddziałują archiwa, kształtując świadomość, wpływając na postawy, wywołując potrzeby. Obecność archiwów w przestrzeni publicznej widoczna jest poprzez działania i informowanie o nich, współpracę z innymi podmiotami, budowanie relacji z publicznością i umiejętne wykorzystanie współczesnych środków komunikowania, w tym także mediów. 
MARLENA JABŁOŃSKA

ORCID 0000-0001-7189-9007

mjablon@umk.pl

(Nicolaus Copernicus University in Toruń)

\title{
ARCHIVES IN SPACE. PEOPLE, PLACES, ACTIVITIES. INTRODUCTION TO THE ISSUE OF THE PRESENCE OF ARCHIVES IN PUBLIC SPACE
}

Keywords: public space of archives, users of archives, digital archives, social functions of archives

\begin{abstract}
The objective of the article is to introduce the deliberations on contemporary presence of Polish archives, and state archives in particular, in public space. Drawing attention to their environment and importance of undertaken activities, while inviting discussion about areas of their activity, used instruments as well as the prospect of mental and organizational changes. Presence of archives in public space is undisputed. It is guaranteed first and foremost by their physicality: the building, people, the holdings. But they are also present in the virtual dimension - as digital archives, binary data clouds, electronic repositories of digital resources. They use the virtual reality to communicate with stakeholder groups and to derive information about the world and people, their real and potential users. They develop electronic archival aids to make them accessible in the digital world and create a multidimensional information system about archives and their resources. Finally, archives are present in the emotional sphere - as archives of memory, thesauri of memories, sources of identity, self-determination and sense of continuity. These are the relationships that people build and discover while researching archival materials. These three dimensions, physical, virtual and emotional, intersect, complement and co-create the environment in which the archives function. They create the public space of the archives. A very important element of this space are its surroundings. People and institutions that interact with the archives, create an audience, form an opinion, review activities. An environment that should have a real impact on the functioning of the archives, the tasks they carry out and their organization, and which the archives are influencing by shaping awareness, affecting attitudes, and evoking needs. The presence of archives in public space is visible through activities and information about them, cooperation with other entities, building relations with the public and skillful use of modern means of communication, including the media.
\end{abstract}


Archiwa są obecne w przestrzeni publicznej, było tak, jest i zapewne będzie. Obecność tę możemy rozpatrywać przynajmniej w trzech wymiarach: realnym, wirtualnym i emocjonalnym. Pierwszy z nich związany jest z miejscem - fizyczną i strukturalną przestrzenią, w której archiwa funkcjonują. Przybierają bowiem one formę instytucjonalną, mają swoją siedzibę, zasób, personel i użytkowników. Są to archiwa instytucje i archiwa instytucji. Realne podmioty, o określonym statucie, źródłach finansowania, zdefiniowanych zadaniach, prawach i obowiązkach. Mają swoje miejsce w topograficznej przestrzeni miasta lub strukturze organizacyjnej instytucji. Drugi wymiar - wirtualny - ściśle wiąże się z cyfrową postacią zgromadzonego zasobu. Nikt chyba już nie ma wątpliwości, iż współczesne archiwa funkcjonują w przestrzeni wirtualnej - jako archiwa cyfrowe, chmury danych binarnych, elektroniczne repozytoria zasobów cyfrowych. Przechowują one materiały, które powstały w swej cyfrowej postaci oraz te, które zostały przekształcone w procesie digitalizacji. Wykorzystują wirtualną rzeczywistość, by komunikować się z grupami interesariuszy i by czerpać informacje o świecie i ludziach, swych realnych i potencjalnych użytkownikach. Opracowują elektroniczne pomoce archiwalne, by je udostępniać $\mathrm{w}$ świecie cyfrowym i tworzyć wielowymiarowy system informacji o archiwach i ich zasobie. I wreszcie, archiwa są obecne w sferze emocjonalnej. Tutaj jako archiwa pamięci, jako tezaurusy wspomnień, wzruszeń i uniesień, jako źródło tożsamości, samostanowienia i poczucia ciągłości trwania. To ludzie w archiwaliach i ludzie w archiwach. To relacje, które ludzie budują i które odkrywają, badając archiwalia. To emocje zapisane na dawnej fotografii, w czarno-białym filmie i w dźwiękach staromodnych płyt, w kształcie ich pamięci.

Przestrzenie te wzajemnie się krzyżują, dopełniają i współtworzą środowisko, w którym archiwa funkcjonują. Celem artykułu jest wprowadzenie do rozważań nad współczesną obecnością polskich archiwów w przestrzeni publicznej ze szczególnym uwzględnieniem archiwów państwowych. Zwrócenie uwagi na ich otoczenie oraz wagę podejmowanych działań.

Archiwa w przestrzeni publicznej obecne są poprzez fakt ich istnienia. Są bowiem powołane do określonych zadań, wypełniają powierzone obowiązki, realizują nałożone funkcje. Codzienna praca rzadko zmusza do refleksji i stawiania pytań generalnych. Pytań o to, komu ma ona służyć? W wypadku archiwów jest to jednak pytanie ważne. Pracując bowiem nad tym co minione, wykorzystując współczesną wiedzę, metody i narzędzia pracy, archiwiści muszą wybiegać w przyszłość i określać potrzeby archiwów i ich użytkowników w dekadach, które przed nimi. Ażeby móc sprawnie funkcjonować w tych trzech wymiarach, niezbędna jest wiedza o przestrzeni, o ludziach i instytucjach, które $\mathrm{z}$ archiwami wchodzą w relacje. Ta przestrzeń, to otoczenie instytucji, które bez względu na profil jej działalności, status, wielkość czy realizowane zadania, tworzą interesariusze. Jednostki bądź zbiorowości, które mogą wpływać na osiąganie przez organizację celów lub na które może wpływać sama organizacja, realizując 
swoje cele ${ }^{1}$ Każda instytucja w toku swojej działalności kreuje własne otoczenie. Podobnie jest $\mathrm{z}$ archiwami, które jako organizacje o określonych funkcjach i zadaniach nawiązują relacje $\mathrm{z}$ różnymi grupami interesariuszy i to zarówno instytucjonalnymi, jak i indywidualnymi. Ich identyfikacja jest bardzo istotna ze względu na strategiczne zarządzanie instytucją i opracowanie programu działań, jakie wobec wybranych grup podejmowane będą w przyszłości². Jest także bardzo ważna ze względu na komunikację z otoczeniem, poruszaną problematykę, język, narzędzia i techniki. Efektem końcowym identyfikacji i analizy grup otoczenia jest utworzenie strategii zarządzania relacjami z określonymi interesariuszami ${ }^{3}$. Przekaz bowiem musi być dostosowany do grup odbiorców, bo tylko wtedy ma on szansę zostać przyjęty zgodnie z intencją i przyniesie pożądany efekt. Błędem zatem jest założenie, że odbiorcami działań oraz informacji o nich wysyłanych przez organizację są „wszyscy”, bliżej nieokreślona opinia publiczna, niezidentyfikowana publiczność czy media, które czasem podnoszone są do rangi odbiorców komunikatów, a nie ich dystrybutorów, traktowane jako całość otoczenia, a nie jego składowa.

Określone grupy interesariuszy tworzą przestrzeń archiwów, ich naturalne środowisko. W przestrzeni tej wyróżnić należy podmioty, które pozwalają im realizować statutowe funkcje, w wypadku archiwów państwowych będzie to: gromadzenie, przechowywanie, opracowanie i udostępnianie zasobu archiwalnego. Naturalną przestrzeń działań w obszarze gromadzenia tworzą podmioty nadzorowane, czyli instytucje, które objęte są nadzorem archiwalnym, ich registratury i archiwa bieżące. Będzie to m.in. administracja państwowa i samorządowa, jednostki kultury, szkoły i wyższe uczelnie, placówki medyczne i inne wytypowane podmioty zgodnie z obwiązującymi przepisami. Dzięki dobremu rozpoznaniu tej przestrzeni, dokładnemu określeniu zasad i procedur nadzoru, zbudowaniu relacji pomiędzy nadzorującym i nadzorowanym oraz sprawnej komunikacji, realizacja zadań związanych z procesem kształtowania państwowego zasobu archiwalnego przebiega bez większych zakłóceń. Osoby pracujące w nadzorze budują relacje, wykorzystując spotkania bezpośrednie, rozmowy telefoniczne, korespondencję elektroniczną. W ten sposób kształtują pozycję i obraz archiwum państwowego w przestrzeni publicznej, w wyobrażeniu tej zdefiniowanej i dookreślonej grupy docelowej. Swoim autorytetem wspierają także funkcjonowanie archiwów bieżących oraz ich pozycję w strukturze organizacyjnej instytucji. Spotkania i rozmowy, także z osobami niezwiązanymi bezpośrednio z archiwum, są okazją do ich pokazania, porozmawiania o specyfice wykonywanych zadań, ich roli i znaczeniu dla regionu i jego mieszkań-

${ }^{1}$ M. Jabłońska, Nowe wyzwana archiwów. Komunikacja społeczna i public relations, Toruń 2016, s. 131.

${ }^{2}$ M. Łukasiuk, PR Ngosów. Komunikacja strategiczna organizacji pozarządowych, Warszawa 2014, s. 73.

${ }^{3}$ A. Adamus-Muszyńska, Wstęp do praktyki public relations, Katowice 2012, s. 18. 
ców oraz dla samej instytucji. Ma to także realny wpływ na kształt świadomości dokumentacyjnej i archiwalnej tej określonej społeczności i ich własnego otoczenia. Protokół wizytacji i zalecenia pokontrolne mają swoją moc urzędową, pokazują kierunek działań i potrzebę przeprowadzenia zmian, i to już nie tylko mentalnych, ale i realnych. Im lepiej bowiem prowadzone archiwum bieżące, tym większa szansa na przygotowanie, w zgodzie ze sztuką archiwalną, materiałów do przekazania archiwum państwowemu. Gromadzenie bowiem, to jedna z podstawowych funkcji realizowanych przez archiwa. Podmioty nadzorowane stanowią tu zupełnie naturalne środowisko działań archiwów państwowych, ale pozostają także do zagospodarowania podmioty, które nie są objęte nadzorem. Mowa tu o archiwach prywatnych, archiwach stowarzyszeń i organizacji różnego typu działających w Polsce i poza jej granicami, które posiadają materiały ważne i cenne z punktu widzenia narodowego dziedzictwa dokumentacyjnego, czy także archiwa podmiotów komercyjnych. Istotne jest rozpoznanie tego środowiska, wytypowanie podmiotów tworzących grupy docelowe, nawiązanie współpracy, budowanie i podtrzymywanie relacji ${ }^{4}$. Spotkania z twórcami, realnymi i potencjalnymi depozytariuszami są wyśmienitą okazją do rozmowy o przeszłości, o potrzebie dokumentowania i dbania o przeszłość. To doskonała możliwość pokazania instytucji i związanych z nią ludzi, ale także wyśmienita okazja do spotkań ludzi, którym archiwum stało się bliskie, dla których jest to miejsce powierzenia dokumentów z rodzinnych archiwów, a nawet bardzo cennych materialnie kolekcji i zbiorów. Dzięki właściwej reakcji archiwistów na taką społeczną potrzebę, do magazynów archiwalnych mogą trafić bezcenne materiały, dokumentujące nie tylko historię regionalną, ale i światową, które w innych okolicznościach i przy negatywnym wizerunku mogłyby zostać przekazane innym niż archiwa instytucjom. Działania te bowiem wpływają na sposób postrzegania archiwów, tego, jak wykonują swoją prace i jak umieją jednać wokół wspólnej idei określoną społeczność. Pokazują także, jak potrafią zagospodarować potencjał tej części otoczenia, poprzez zaproszenie do współpracy, w ramach crowdsourcingu czy konsultacji, doradztwa, obecności podczas wydarzeń, także w charakterze znawcy tematu, eksperta. I wreszcie, samo przejęcie cennych materiałów do zasobu archiwum państwowego, które nierzadko chroni je przed zniszczeniem, jest pretekstem do uzyskania rozgłosu, przygotowania konferencji prasowej, nawiązania współpracy z mediami, pokazania instytucji na zewnątrz w określonym, zaplanowanym wcześniej kontekście. Archiwum jako instytucja o statusie ius archivi, gwarantująca społeczeństwu wiarygodność i poczucie bezpieczeństwa, staje się także powiernikiem pozainstytucjonalnych źródeł historycznych, spoczywających dotychczas w prywatnych rękach. Należy

${ }^{4}$ R. Degen, M. Jabłońska, Collecting projects $i$ documentation strategies jako narzędzia ksztaltowania zasobu archiwalnego i budowania wizerunku archiwów, [w:] Archiwa organizacji pozarzadowych w Polsce, pod red. T. Czarnoty, M. Konstankiewicza, Lublin 2015, s. 167-173. 
jednak pamiętać, że zasób instytucji nieobjętych nadzorem archiwalnym, może być równie atrakcyjny dla innych podmiotów. Mogą być to archiwa z powierzonym zasobem lub wyodrębnione, archiwa społeczne i izby pamięci, biblioteki, muzea, stowarzyszenia i inne organizacje, które realizują podobne cele jak archiwa państwowe. W tym miejscu i w tym kontekście mowa jest o konkurencji, czyli instytucjach, które zabiegają nie tylko o użytkowników czy pracowników, ale przede wszystkim o cenne dla zachowania pamięci materiały. Jest to kolejny element otoczenia archiwów państwowych, o którym nie można zapominać. Tutaj do głosu dochodzi przewaga konkurencyjna i te cechy instytucji, które wyróżniają ją z grona pozostałych. Profesjonalizm w działaniu, wysoka kultura pracy, wrażliwość historyczna i dokumentacyjna, zaangażowanie i determinacja w dążeniu do celu, to cechy bardzo ważne w zawodzie archiwisty. Ważne jednak również z punktu widzenia samej instytucji i jej pozycji w przestrzeni publicznej. Archiwa tworzą ludzie i to w dużej mierze od nich zależy obraz tej instytucji w społeczeństwie. Pomocne w budowaniu tego pożądanego obrazu są media kolejny element otoczenia archiwów. Tradycyjne - prasa, radio, telewizja, które wymagają zaangażowania i współpracy z dziennikarzami - i te elektroniczne, stwarzające dodatkową przestrzeń dla samych archiwów do autoprezentacji, zdobywania własnej publiczności i wchodzenia z nią w relacje. Bycie online to nie tylko przywilej, ale wręcz obowiązek współczesnych instytucji. Internet bowiem stał się głównym przekaźnikiem informacji. Elektroniczne bazy danych dostępne online, zasoby cyfrowe i dostęp do nich, strony internetowe, e.korespendencja i obecność na profilach społecznościach wymagają zaangażowania, wiedzy i określonych umiejętności, ale też stwarzają wiele dawniej nieznanych archiwom możliwości. Są dziś pewnym znakiem współczesności, synonimem nowoczesnego zarządzania instytucją, narzędziem komunikacji i źródłem wiedzy o archiwach udostępnianym na zewnątrz oraz zmieniającym się w zawrotnym tempie świecie. Internet pozwala badać nastroje społeczne, oczekiwania i potrzeby, umożliwia też wywoływanie określonych postaw, rozbudzanie ciekawości, zachęca do interakcji. I pomimo że archiwa to stałość, a Internet zmienność, to jedno nie wyklucza drugiego. Użytkownicy Internetu także tworzą otoczenie archiwów, wpływają na ich działalność, czerpią z nich korzyści i kreują obraz instytucji w wirtualnym i realnym świecie.

Celem nadrzędnym archiwów państwowych jest trwałe zachowanie świadectw przeszłości i zapewnienie do nich dostępu w celu wspierania rozwoju państwa i społeczeństwa obywatelskiego ${ }^{5}$. Zgromadzony zasób musi być zatem zabezpieczony i przechowywany w warunkach optymalnych. Temu służyć mają specjalnie zaprojektowane i wyposażone budynki archiwalne, nowoczesne magazyny i specjalistyczne opakowania. Infrastruktura ta tworzy materialną prze-

${ }^{5}$ Strategia archiwów państwowych na lata 2010-2020, Warszawa 2011, https://www.archiwa. gov.pl/images/docs/Strategia_archiww_pastwowych na_lata_2010_2020.pdf [dostęp: 20.04.2019]. 
strzeń funkcjonowania archiwów, ale także generuje nowe grupy interesariuszy zewnętrznych. Otóż są to podmioty komercyjne, które dostarczają archiwom produktów i usług. Projektują, sprzedają, udostępniają systemy i podsystemy, całą infrastrukturę lub jej część, świadczą określone usługi. Wchodzą w relacje $\mathrm{z}$ archiwum, wpływają na jego funkcjonowanie, a w dłuższej perspektywie na jego wizerunek. Kształtują swoje wyobrażenie o instytucji. Podobnie jest w wypadku opracowania zasobu. Jest to jedna z wewnętrznych funkcji archiwów państwowych, ciągle jeszcze realizowana przez personel własny, ale coraz częściej wspierany przez podmioty zewnętrzne, osoby i firmy. Są to praktykanci, stażyści, wolontariusze, osoby zatrudnione na umowy krótkoterminowe, ale i firmy świadczące usługi digitalizacji czy wsparcia IT. Oni także tworzą realną grupę otoczenia archiwów państwowych.

$\mathrm{Z}$ otoczeniem instytucji wydają się być powiązane najmocniej te czynności, które wymagają kontaktu bezpośredniego $\mathrm{z}$ odbiorcami oferowanych usług. W wypadku archiwów bez wątpienia będzie to nieodpłatne udostępnianie i wiele zadań związanych z jego realizacją. W pracowni naukowej realna grupa użytkowników może badać zgromadzony zasób, poszukując potrzebnych informacji, korzystając z oryginalnych materiałów archiwalnych lub ich kopii w postaci mikrofilmów, jak też skanów. W tej grupie znajdą się profesjonaliści, naukowcy, badacze wielu dyscyplin, zawodowi genealodzy, ale także i amatorzy odkrywający dzieje swojej rodziny. Każdy z nich ma swoje określone oczekiwania, potrzeby i możliwości. Wśród użytkowników wyróżnia się osoby prywatne i przedstawicieli instytucji; tych, którzy samodzielnie prowadzą badania, i tych, którzy zlecają wykonanie kwerend, tych, którzy pracują na oryginałach, i tych, którzy korzystają z publikowanych kopii, także dostępnych w Internecie skanów. Część z tych osób, pomimo że nigdy fizycznie w danym archiwum nie była, to ma pewne wyobrażenie o jego funkcjonowaniu, ma swoje doświadczenie i swój jego obraz. I wreszcie ci, którzy uczestnicząc $\mathrm{w}$ wydarzeniach popularyzujących historię i zasób archiwów, stykają się z nimi okazjonalnie. Nie są to wizyty regularne, a ich celem nie jest przeprowadzenie badań, ale rozwijanie indywidualnych pasji i zainteresowań. Uczestnicy archiwalnych spotkań z historią, pikników historycznych, wystaw stałych i czasowych, prelekcji, pokazów, warsztatów i lekcji archiwalnych, spotkań autorskich i innych form aktywności archiwów, stanowią bowiem ich publiczność, a przez to ważny element otoczenia. Działania z zakresu popularyzacji są powiązane $\mathrm{z}$ udostępnianiem zasobu, a nawet uznawane są za jedną z jego form, a funkcja edukacyjna archiwów za kolejny obszar ich działalności ${ }^{6}$. Organizacja wydarzeń tego typu wymaga dużego nakładu sił i środków, obciąża archiwa organizacyjnie, nierzadko i finansowo. Jest jednak wyśmienitą okazją do poznania swojego zespołu i integracji pracowników, sprawdzenia

${ }^{6}$ Zob.: A. Rosa, Funkcja edukacyjna archiwów, Warszawa 2012, i D. Grot, Ku przeszłości otwartej. Dostępność archiwów państwowych w Polsce w latach 1918-2014, Warszawa 2015. 
swojej oferty i poznania jej odbiorców, a także nawiązania współpracy z innymi organizacjami. Mogą być to galerie, biblioteki i muzea, które chętnie włączą się merytorycznie we współorganizację wydarzenia; przedsiębiorcy, którzy ufundują nagrody lub sfinansują część imprezy; władze lokalne, które obejmą patronat honorowy nad wydarzeniem, i media, które wydarzenie nagłośnią, ale także szkoły i wyższe uczelnie, które z jednej strony mogą być odbiorcami oferty, jak również jej współtwórcami. Wszystkie te podmioty stają się automatycznie częścią otoczenia organizatora, czyli archiwum. Samo archiwum w tych działaniach ma status gospodarza, partnera, kreatora, lidera wydarzenia, który świadomie i odpowiedzialnie kształtuje wizerunek instytucji w wyobrażeniu współtwórców i też odbiorców działań.

Archiwa państwowe, oprócz realizacji swoich podstawowych funkcji, są instytucjami, które podlegają określonym uwarunkowaniom prawnym. W związku z czym w ich otoczeniu odnaleźć można prawodawców, przedstawicieli organów nadzorujących i kontrolujących, a także przedstawicieli Ministerstwa Kultury i Dziedzictwa Narodowego jako organu zwierzchniego. Ponadto, w otoczeniu archiwów znajdują się liderzy opinii, czyli osoby, które poprzez swój autorytet, dorobek, pełnione funkcje są ambasadorami archiwów, zabiegają o ich interesy, budują pozytywną wokół nich atmosferę. Dobra atmosfera ważna jest także w relacjach w miejscu pracy. Archiwa państwowe bowiem to także duży pracodawca. W sieci pracuje obecnie ponad 1570 osób, z czego większość to archiwiści, ale także pracownicy obsługi i administracji, konserwatorzy i pracownicy naukowi. Ich nastawienie do codziennych obowiązków, wzajemne relacje i poziom satysfakcji z pracy wpływają na jakość realizowanych zadań. Oni wraz ze swoimi bliskimi tworzą otoczenie wewnętrzne instytucji i kreują jej wizerunek. Są bezpośrednim odbiorcą zmian zachodzących w instytucji i łącznikiem pomiędzy archiwum i jego publicznością. W sposób realny wpływają na jego kształt i funkcjonowanie.

Tak jak zmienne jest otoczenie archiwów, tak też zmieniają się one same. Widać to $\mathrm{w}$ warstwie realnej, w infrastrukturze archiwów. Ich budynki i wyposażenie zmieniają się na oczach publiczności. W latach 2013-2018 oddano do użytku nowe siedziby archiwów państwowych w Gorzowie Wielkopolskim, Radomiu, Zielonej Górze, Bielsku-Białej, Rzeszowie i Białymstoku. Przebudowano i zmodernizowano obiekty w: Bolesławcu, Lublinie, Gdańsku i Międzyzdrojach. Kontynuowane są prace budowlane w Krakowie i Suwałkach, a w przygotowaniu są inwestycje w Bydgoszczy, Katowicach, Koszalinie, Łodzi, Piotrkowie Trybunalskim, Poznaniu, Szczecinie oraz Nowym Sączu. Są to nowoczesne obiekty, które zapewniają powierzchnie magazynowe przystosowane do przejmowania dokumentów w wieloletniej perspektywie, o optymalnych warunkach

${ }^{7}$ Inwestycje budowlane, https://www.archiwa.gov.pl/pl/o-nas/inwestycje-budowlane [dostęp: 20.08.2019]. 
przechowywania. Mają także pracownie naukowe, wyposażone w komputery i stanowiska do samodzielnego skanowania dokumentów, pracownie konserwacji i digitalizacji zbiorów oraz sale wystawiennicze i konferencyjne, które już w swym założeniu mają pełnić funkcje miejsc spotkań i wydarzeń kulturalnych. Warto w tym miejscu zaznaczyć, iż obok atrakcyjnej przestrzeni ważna jest dobra lokalizacja, dostępność budynku, łatwa komunikacja. Centrum miasta, gdzie życie kulturalne i towarzyskie się toczy, czy bliskość węzłów komunikacyjnych, bezpośrednio bowiem przekładają się na frekwencję i mają wpływ na charakter uczestników oferowanych wydarzeń. To właśnie w pracowni naukowej i podczas wystaw użytkownicy realni i potencjalni mogą obcować z zapisaną $\mathrm{w}$ dokumencie historią, analizować źródła i poznawać przeszłość. Podczas warsztatów zgłębiają arkana pracy kancelarii w wiekach dawnych, poznają zawód archiwisty, odkrywają formy dokumentowania, uczą się podstaw profilaktyki i konserwacji papieru i skóry. W przestrzeni archiwum dochodzi do interakcji pomiędzy „nimi a nami”. Pozwala to oswoić miejsce, lepiej je poznać, uczynić sobie przyjaznym. A to pierwszy krok do kształtowania świadomego i dobrze przygotowanego do prowadzenia badań użytkownika.

Przestrzeń archiwów nie powinna być zarezerwowana tylko dla nich samych. Nawet przeciwnie, powinna stać się wspólną przestrzenią spotkań z przeszłością. Dostępna dla osób reprezentujących różne obszary aktywności, pasjonatów historii, regionalistów, genealogów, badaczy wielu dyscyplin. Miejscem, do którego chętnie się wraca, które wywołuje ciąg pozytywnych skojarzeń. To jest coś, co pozwala tchnąć w archiwa nowe życie, odświeżyć je, pokazać jako atrakcyjne, pełne wiedzy o życiu i ludziach, państwie i jego obywatelach. To tutaj bowiem łączy się pasja miłośnika przeszłości z pasją archiwisty, który zna klucz do odkrywania tego co minione.

Archiwa stanowią także miejsce spotkań w wymiarze wirtualnym. Jednorodna identyfikacja wizualna na stronach internetowych i ujednolicony system zarządzania treścią systematyzują dostarczane informacje i kreują obraz skonsolidowanej sieci. Natomiast zintegrowany system informacji archiwalnej, szukajwarchiwach.gov.pl, i inne bazy, mają na celu z jednej strony dostarczenie maksimum potrzebnej informacji o zasobie archiwum, a z drugiej pokazują prowadzoną przez archiwa państwowe politykę dostępności do gromadzonych danych. W miejscu tym użytkownik może spotkać się nie tylko z archiwum, ale i z cyfrową kopią interesującego go dokumentu. Z profilu archiwum na portalach społecznościowych dowiaduje się o ciekawych wydarzeniach, a na forach dyskusyjnych może zadać pytanie dotyczące zasobu archiwum, zasad jego opracowania i udostępniania, regulacji prawnych czy samej w nim pracy. Archiwa państwowe wykorzystują dziś najpopularniejsze portale, tj. Facebook, Instagram, YouTube, choć ciągle stopień ich wykorzystania nie jest satysfakcjonujący.

Trudno także wyobrazić sobie spotkania bez uczestników i dobrej atmosfery. Wydarzenia $\mathrm{w}$ archiwach to ludzie i emocje, które tym wydarzeniom towarzy- 
szą. To kolejny, emocjonalny wymiar obecności archiwów w społeczeństwie. Polityka otwartości widoczna w doborze tematyki i formy proponowanych imprez, życzliwość w stosunku do uczestników spotkań, gotowość do dyskusji, zgłębiania zagadnień oraz zaspokajania ich ciekawości - to buduje pozytywne relacje.

Bez wątpienia aktywna i zaangażowana obecność archiwów w przestrzeni publicznej przynosi im wiele korzyści. Rozpatrywać je można w dwóch wymiarach: instytucjonalnym (archiwa) i społecznym (otoczenie archiwów) ${ }^{8}$. Archiwa, funkcjonując w społeczeństwie, realizują swoje podstawowe zadania. Pracują dla społeczeństwa gromadząc, zapisy ludzkiej działalności, przechowując je w warunkach najlepszych z możliwych, opracowując z myślą o swoich użytkownikach i udostępniając na potrzeby państwa i obywateli. Prowadząc otwartą politykę komunikacyjną, mają okazję dzielić się wiedzą o istnieniu archiwów i ich bogatej historii, funkcjach i zadaniach, specyfice pracy oraz wartościach i celach, które im przyświecają. Daje to możliwość pokazania archiwów państwowych jako ważnych i użytecznych, społecznie potrzebnych, godnych zaufania i finansowania ze środków publicznych. Pozwala oczekiwać od społeczeństwa zaangażowania w sprawy archiwów, lobbowania na ich rzecz, wsparcia w sytuacjach kryzysowych i trudnych dla samej instytucji oraz pomocy w realizacji zadań i osiągania celów. Poprzez współpracę z otoczeniem wzrasta wzajemne zaufanie i zainteresowanie. Archiwa zatem mogą liczyć na większe uznanie dla swojej działalności i pracy swoich pracowników, na większą liczbę użytkowników ich zasobu, darczyńców indywidualnych i instytucjonalnych, którzy obdarzając archiwum zaufaniem, oddają, do jego magazynów własną dokumentację, i wreszcie, współorganizatorów ważnych, z punktu widzenia wyznaczanych sobie celów, imprez naukowych i popularno-naukowych, oraz sponsorów, którzy ich przygotowanie wspierają. Wydarzenia te, to wyśmienita okazja do pokazania gmachu archiwum, jego przestrzeni publicznej oraz tej zarezerwowanej nierzadko wyłącznie dla pracowników, jego wyposażenia, estetyki i funkcjonalności. Szczególnie to istotne w wypadku archiwów, które zmieniają się nie tylko organizacyjnie, ale i fizycznie, rozbudowując się, modernizując swoje siedziby, oddając do użytku nowe obiekty. To także ważne właśnie z punktu widzenia organizacji pracy i funkcjonowania archiwów. Stwarza bowiem przestrzeń do rozmowy o mocnych i słabych stronach działalności konkretnych instytucji. Wysłuchania głosu tych, którzy z archiwów korzystają i mają wobec nich określone oczekiwania. Dają impuls do autorefleksji, do sprawdzenia siebie i wyciągnięcia nauki z kolejnych, nowych doświadczeń. Aktywność w przestrzeni publicznej daje zatem archiwom wiedzę o innych i o sobie. Pozwala bliżej poznać otoczenie, poznać siebie. Motywuje do ciągłego uczenia się, poznawania nowych narzędzi, odkrywania nowych obszarów, rozpoznawania własnego zasobu i zasobu innych archiwów, wyznaczania nowych,

\footnotetext{
${ }^{8}$ M. Jabłońska, op.cit., s. 179-186.
} 
ambitnych celów. Zachęca do poznawania swoich użytkowników, zmieniającej się społeczności, której potrzeby, umiejętności i oczekiwania ewoluują. Archiwa mają także okazję wyraźnie zaznaczyć, że w relacjach z innymi instytucjami są partnerem. Nie tylko świadcząc usługi, wykonują pracę dla innych, ale wchodząc w relacje, oczekują równego traktowania, oznaczania ich obecności w projektach, informowania o wykorzystaniu ich zasobu w publikacjach, podawania nazwy archiwum jako współtwórcy dzieła lub wydarzenia.

Korzyści płynące ze wzrostu publicznej aktywności archiwów państwowych można rozpatrywać również przez pryzmat zatrudnionych tam osób. Ich obecność w przestrzeni społecznej daje możliwość pokazania profesji, specyfiki wykonywanych zadań, warunków pracy, wykształcenia, umiejętności. Jest okazją do zaprezentowania siebie jako osoby z olbrzymią wiedzą, zaangażowanej w popularyzację historii, znawcę różnych typów dokumentacji, regionalistę i pasjonata. Pozwala pochwalić się znajomością języków obcych, paleografii i neografii, prawa i administracji oraz podstawowych zasad profilaktyki i konserwacji materiałów archiwalnych. Wszystko to wpływa na podniesienie świadomości społecznej i pokazuje na zewnątrz, kim jest archiwista. Jest to bez wątpienia element walki ze stereotypami. Jest szansą na wzrost atrakcyjności zawodu i samozadowolenia z jego wykonywania. Być może z czasem pozwoli na zmniejszenie rotacji pracowników i pozyskanie nowych, dobrze wykształconych i zaangażowanych. Stwarza przestrzeń do rozmowy o wzroście nakładów na prowadzenie archiwów, a co za tym idzie wzroście wynagrodzenia ich pracowników. Spotkania z ludźmi, uczestnikami różnych wydarzeń, to także okazja do poznania siebie, pokonywanie własnych barier, uczenie się poprzez doświadczenie i wyznaczanie sobie kolejnych, zawodowych celów.

Pracownicy są bardzo ważnym podmiotem w rozważaniach nad obecnością archiwów w przestrzeni publicznej. Nie byłoby jednak archiwów bez ich zasobu i nie należy o tym zapominać. To właśnie materiały archiwalne stanowią najczęściej podstawę podejmowanych działań, a czasami i pretekst do ich organizacji. Zawsze są jednak obecne. Większa aktywność archiwów państwowych, to bez wątpienia większa ich rozpoznawalność, wyższa kultura dokumentacyjna i świadomość archiwalna. To sprzyja wzrostowi zaufania do instytucji i w konsekwencji ma realne przełożenie na zasób archiwum. Łatwiej jest bowiem pozyskiwać darczyńców i depozytariuszy, a tym samym wzbogacać swój zasób, prowadzić akcje crowdsourcingowe i opracowywać materiały, których bez pomocy z zewnątrz nie można było opracować. To przekładać się może na stopień wykorzystania materiałów archiwalnych w amatorskich poszukiwaniach, ale i w badaniach naukowych, procesach sądowych czy dyskursie politycznym. Społeczna świadomość istnienia archiwów daje wzrost zainteresowania zasobem archiwalnym, wywołuje potrzebę prowadzenia badań naukowych i poszukiwań, np. genealogicznych albo socjalnych. W ten sposób wzrasta liczba użytkowników, a zgromadzone w magazynach archiwalnych materiały okazują się 
ważne i potrzebne z perspektywy pojedynczego człowieka, nie tylko zbiorowości. Rosnące zainteresowanie zasobem, to także potrzeba prowadzenia prac nad jego opracowaniem, nad stworzeniem optymalnych narzędzi wyszukiwania oraz poprawy warunków ich przechowywania oraz digitalizacji.

Obecność archiwów państwowych w przestrzeni publicznej, to również korzyści płynące dla społeczeństwa. Każdy, kto tylko zechce, ma szansę dowiedzieć się, czym są archiwa i jakie materiały gromadzą, kto z tych materiałów może korzystać i na jakich zasadach, jak tworzy się archiwa i jak została ukształtowana współczesna sieć archiwów w Polsce. To często wiedza dodatkowa, spoza szkolnej podstawy programowej, ale ważna, szczególnie jeśli okaże się użyteczna. To wiedza, która wpływa na postawę społeczną, na wrażliwość historyczną i świadomość potrzeby zabezpieczania śladów przeszłości. Pobudza ona ciekawość oraz zachęca do aktywności zarówno badawczej, jak i dokumentacyjnej. Tworzy potrzebę korzystania ze źródeł archiwalnych, także zachęca do ich wywoływania (np. działalność dokumentacyjna, oral history), zabezpieczania (np. archiwa społeczne, izby pamięci) lub opracowywania (np. crowdsourcing, wolontariaty). Aktywność archiwów państwowych w społeczeństwie, to także zapraszanie do współpracy. Zachęcanie do udziału w wydarzeniach, włączanie się w ich organizację, współtworzenie, branie za nie współodpowiedzialności (np. „Zostań rodzinnym archiwistą”, „Archiwa Rodzinne Niepodległej”). To poczucie bycia częścią globalnej historii. To także okazja do skorzystania z często atrakcyjnej oferty edukacyjnej adresowanej do szkół, uczniów i nauczycieli, też do osób indywidualnych. Niecodzienne lekcje historii, przeprowadzane w gmachu archiwum rozbudzają wyobraźnię uczestników i na dłużej zapadają w pamięć. To doświadczanie przeszłości, a tym samym dbanie o pamięć.

Archiwa państwowe, funkcjonując w przestrzeni publicznej ponad 100 lat, zgromadziły imponujący dorobek. Ich zasób liczy ponad $47 \mathrm{mln}$ j.a. ${ }^{9}$ Rocznie ich pracownie naukowe odwiedza blisko 28 tys. osób, korzystając z niespełna $1,2 \mathrm{mln}$ j.a. Ponadto każdego roku, na zlecenie instytucji i osób prywatnych, archiwa państwowe wykonują kwerendy, których liczba oscyluje wokół 70 tys. Przyjmują wycieczki, organizują wystawy i pokazy, opracowują i realizują projekty edukacyjne, publikują i współpracują z mediami. Obecnie zatrudniają ponad 1570 osób. Ale także realnie wpływają na kształt przyszłego zasobu archiwalnego, nadzorując podległe im jednostki i pozyskując materiały archiwalne od swoich darczyńców, oddziałują na kształt, zakres i sposób opracowania zasobu, sprawują pieczę nad zgromadzonymi materiałami archiwalnym, również je udostępniają, w sposób bezpośredni i pośredni oraz poprzez działania popularyzatorskie.

\footnotetext{
9 Sprawozdanie Naczelnego Dyrektora Archiwów Państwowych KN-1 działalność archiwalna według stanu na dzień 31 grudnia 2018 r., https://www.archiwa.gov.pl/files/KN-1_2018.pdf [dostęp: 20.08.2019].
} 
$\mathrm{Na}$ przestrzeni lat funkcje archiwów ewoluowały, a punkt ciężkości w ich pracy coraz bardziej przesuwał się z zasobu na użytkownika ${ }^{10}$. Zmianie ulegała polityka dostępności źródeł i otwartości archiwów. Przeszły one bowiem długą drogę od archiwów stanowiących narzędzie władzy i pracowni będących azylem naukowych poszukiwań, zarezerwowany tylko dla grup uprzywilejowanych, do miejsc spotkań ludzi, do instytucji kulturotwórczych, których oferta naukowa i popularno-naukowa jest godna uwagi i wpływa na postawy jednostek i zbiorowości ${ }^{11}$. Wydaje się, że funkcjonując w społeczeństwie opartym na wiedzy, głodnym informacji, ciekawym ludzi i świata, świadomym swoich praw, archiwa powinny iść w kierunku powszechnego dostępu, otwartości, profesjonalizacji świadczonych usług i bardzo dużej świadomości potrzeb, oczekiwań i możliwości. Archiwa państwowe, funkcjonując w świecie i społeczeństwie, muszą zaznaczać swoją użyteczność, w tym przydatność dla państwa i obywateli, oraz atrakcyjność, widzianą jako nowoczesność, ciekawość, otwartość na korzystających, ale i na zmiany, które w przestrzeni społecznej zachodzą. Powinny znać swoją wartość, zaznaczać swoją użyteczność i ciągle dążyć do doskonałości, mierząc się z teraźniejszymi i przyszłymi wyzwaniami.

\section{Bibliografia}

Adamus-Muszyńska A., Wstęp do praktyki public relations, Katowice 2012.

Degen R., Jabłońska M., Collecting projects i documentation strategies jako narzędzia ksztattowania zasobu archiwalnego i budowania wizerunku archiwów, [w:] Archiwa organizacji pozarzadowych w Polsce, pod red. T. Czarnoty, M. Konstankiewicza, Lublin 2015, s. 167-173.

Grot D., Ku przeszłości otwartej. Dostępność archiwów państwowych w Polsce w latach 19182014, Warszawa 2015.

Inwestycje budowlane, https://www.archiwa.gov.pl/pl/o-nas/inwestycje-budowlane [dostęp: 20.08.2019].

Jabłońska M., Nowe wyzwana archiwów. Komunikacja społeczna i public relations, Toruń 2016.

Łukasiuk M., PR Ngosów. Komunikacja strategiczna organizacji pozarządowych, Warszawa 2014.

Menne-Haritz A., Dostęp do archiwów, czyli przeformułowanie archiwalnego paradygmatu, „Archeion" 2002, t. 104, s. 68-95.

Rosa A., Funkcja edukacyjna archiwów, Warszawa 2012.

Sprawozdanie Naczelnego Dyrektora Archiwów Państwowych KN-1 działalność archiwalna według stanu na dzień 31 grudnia 2018 r., https://www.archiwa.gov.pl/files/KN-1_2018.pdf [dostęp: 20.08.2019].

Strategia archiwów państwowych na lata 2010-2020, Warszawa 2011, https://www.archiwa.gov.pl/ images/docs/Strategia_archiww_pastwowych_na lata_2010_2020.pdf [dostęp: 20.04.2019].

${ }^{10}$ A. Menne-Haritz, Dostęp do archiwów, czyli przeformulowanie archiwalnego paradygmatu, „Archeion” 2002, t. 104, s. 68-95.

${ }^{11}$ M. Jabłońska, op.cit., s. 39. 